Отримано: 6 січня 2018 р.

Прорецензовано: 15 січня 2018 р.

Прийнято до друку: 22 січня 2018 р.

e-mail: serhii.rudko@oa.edu.ua

DOI: 10.25264/2409-6806-2018-27-57-61
Рудько С. Наукова діяльність Миколи Василенка наприкінці XIX - на поч. XX ст. / С. Рудько // Наукові записки Національного університету «Острозька академія». Серія «Історичні науки». - Острог, 2018. - Вип. 27 : На пошану Володимира Трофимовича. - С. 57-61.

\title{
Сергій Рудько
}

УДК 930. 1 (477)

\section{НАУКОВА ДІЯЛЬНІСТЬ МИКОЛИ ВАСИЛЕНКА НАПРИКІНЦІ ХІХ - НА ПОЧ. ХХ СТ.}

У статті проаналізовано участь Миколи Василенка в науковому житті підросійської України на межі XIX - ХХ ст., становлення і трансформацію його наукових поглядів. Зроблено висновки про домінування у нього «українського» компонента наукового світогляду з початку XX ст., а особливо після ознайомлення з праиями Михайла Грушевського.

Ключові слова: Микола Василенко, Михайло Грушевський, підросійська Украӥна, науковий світогляд.

\section{Сергей Рудько}

\section{НАУЧНАЯ ДЕЯТЕЛЬНОСТЬ НИКОЛАЯ ВАСИЛЕНКА В КОНЦЕ ХIX - В НАЧ. ХХ СТ.}

В статье проанализировано участие Николая Василенко в научной жизни Украины в составе Российской империи на рубеже XIX - XX вв., становление и трансформация его научных взглядов. Сделаны выводы о доминировании у него «украинского» компонента научного мировоззрения с начала ХХ в., особенно после знакомства с трудами Михаила Грушевского.

Ключевые слова: Николай Василенко, Михаил Грушевский, Украина в составе Российской империи, научное мировоззрение.

\section{Serhii Rudko}

\section{MYKOLA VASYLENKO' SCIENTIFIC ACTIVITY AT THE END OF XIX - THE BEGINNING OF XX CENTURY}

This article is an attempt to analyze the scientific works by M.Vasylenko which have been written until 1917. From the beginning of his work young scientist was most interested in General Theory of Law and State. His scholar authority was greatly increasing. His publications in 'The Brockhaus and Efron Encyclopedic Dictionary' contained forward scientific ideas. The scholar was one of the most active members of The Nestor the Chronicler Historical Community. From 1909 to 1917 M.Vasylenko joined different scientific associations such as Ukrainian Scientific Association and The Taras Shevchenko Scientific Society. The analysis of scientific works by M.Vasylenko shows the Ukrainian element of his mentality become more intensive at that time. M. Hrushevskyi influenced M.Vasylenko in this way. M.Vasylenko moved on M. Hrushevskyi' historical concept and also popularized his works, and actively reviewed it. The most obvious proof of the scientist's move to the position of the national-centered conception of Ukrainian history is contained in 'The Essays on the History of Western Rus and Ukraine', his the most famous research.

Key words: Mykola Vasylenko, Mykhailo Hrushevskyi, mentality, historical concept, Ukrainian history.

Особистість Миколи Василенка - визначного історика, громадського та політичного діяча ще не знайшла широкого висвітлення в історичній літературі. В історіографії наукова діяльність М. Василенка на межі XIX - XX ст. відображена фрагментарно та поверхово. У статті автор на основі архівних матеріалів продемонстрував формування наукового світогляду Миколи Прокоповича.

Дослідженням цієї проблеми займалася Л. Матвєєва [13]. Деякі цінні фактичні відомості про початок наукової діяльності Миколи Прокоповича знаходимо в публікації дружини вченого Н. Полонської-Василенко [15] та його учня В. Гришка [7], а також загальній праці колективу авторів В. Вороненка, Л. Кістерської, Л. Матвєєвої, І. Усенка [4]. 
3 проголошенням незалежності України вийшло кілька публікацій, в яких розглянуто та проаналізовано наукову діяльність М. Василенка. Серед таких досліджень слід відзначити студію М. Петріва, у якій автор опублікував та проаналізував наукову розвідку Миколи Прокоповича про Конституцію П. Орлика 1710 р. [14]. Аналізу творчих взаємин М. Василенка та М. Грушевського у своїх публікаціях присвятив увагу І. Гирич [5; 6].

Джерелами для написання статті послужили архівні фонди Інституту Рукопису Національної бібліотеки України ім. В. І. Вернадського, Центрального державного ахіву-музею літератури і мистецтва України, Центрального державного архіву вищих органів влади та управління України. Окремим видом джерел $є$ наукові праці М. Василенка у сфері історії та права, що є підставами для вивчення історичних поглядів вченого [1-3].

Стаття має на меті розкрити головні напрямки науково-організаційної діяльності М. Василенка в підросійській Україні на межі XIX - XX ст. Серед них, зокрема, організація роботи таких наукових установ, як НТШ, УНТ, Історичне товариство Нестора-літописця та ін., а також публікація низки праць з історико-правової тематики.

Після навчання у Дерптському університеті (нині Тартуський) Микола Василенко переїхав до Києва. Тут він отримав те, чого в науковому сенсі не міг мати в Дерпті: можливість безпосередньо зануритися в джерела історії. У Києві він із задоволенням став вивчати джерела соціальної і економічної історії України. У Києві М. Василенко відвідував лекції та семінари М. Владимирського-Буданова, В. Антоновича, В. Іконнікова, І. Лучицького, працював у архівах, готувався до магістерських іспитів [16, арк. 4].

Під впливом О. Лазаревського М. Василенко зосередив свою увагу на матеріалах історії форм землеволодіння Лівобережної України. Поступово з цього матеріалу викристалізувалася тема його дисертації - «Землеволодіння Лівобережної України XVII-XVIII ст.» [15, с. 41]. Микола Прокопович вважав себе учнем О. Лазаревського. Останній був фактичним редактором журналу «Киевская старина». Саме в цьому журналі М. Василенко почав друкувати свої рецензії і замітки. Першою була його рецензія на «Харківський збірник» - літературно-науковий додаток до Харківського календаря на 1890 р., яка була надрукована в XII кн. Тому 1890 рік, по суті, можна назвати датою початку наукової діяльності М. Василенка [17, арк. 25].

«Киевская старина» незабаром поповнилася низкою його цікавих публікацій: «К вопросу о децентрализации исторических архивов», «К истории малорусской историографии и малорусского общественного строя», «Прикрепление крестьянства левобережной Малороссии в XVIII в.» та ін. Цими працями М. Василенко започаткував свою наукову біографію.

У 1892 р. було опубліковано роботу «Генеральное следствие о маетностях Киевского полка 1729 1730», якою М. Василенко заснував серію видань пам'яток історії і права України [4, с. 55]. Вже 3 початків наукової діяльності молодого вченого найбільше цікавила державно-правова тематика. Тому 3 великої кількості історичних джерел, придатних до вивчення та аналізу, М. Василенко відбирав такі, в яких містився цей аспект.

Його авторитет як науковця помітно зростав. Плідно працюючи в архівах України, Микола Прокопович згодом друкує нові дослідження в енциклопедичному словнику Брокгауза та Ефрона. Участь у цьому виданні ще зовсім молодого вченого була визнанням не тільки його наукових здібностей, а й місця його досліджень у тогочасній науці [13, с. 70-71].

312 жовтня 1908 р. по 11 липня 1909 р. М. Василенко відбував ув'язнення в петербурзькій тюрмі, відомій, як «Кресты». Після виходу на волю Микола Прокопович відходить від співпраці з опозиційною пресою і в період 1909 - 1917 рр. знову активізує наукові дослідження. В останні місяці перед ув’язненням Микола Прокопович підготував до друку і написав передмову до праці О. Лазаревського «Малороссийские посполитые крестьяне». Іншою його працею за цей час було видання «Генеральное следствие о маетностях Черниговского полка», яке вийшло як третій випуск «Материалов по истории экономического, юридического и общественного быта Старой Малороссии» [18, арк. 79].

Твердо вирішивши писати дисертацію, М. Василенко вагався у виборі теми. У нього було багато матеріалу, зібраного на поч. 1890-х pp., з історії форм землеволодіння в Україні XVII-XVIII століть, і він думав про нього. Проте, переглянувши свої матеріали і документи, Микола Прокопович вирішив інакше. Ось що з цього приводу він писав В. Модзалевському: «Переглянув я свої чернетки про монастирське землеволодіння і землеволодіння взагалі та й замислився. Знайомство з працями Фюстель де Куланже відкрило мені нові погляди на історію землеволодіння. Працювати потрібно багато, і 
я боюся брати цю тему для дисертації, хочу узяти вужчу. Думаю зупинитися на магдебурзькому праві в Малоросії» [12, арк. 25].

М. Василенко продовжував збирати матеріали з історії магдебурзького права. Проте ця тема не захопила його цілком, і Микола Прокопович цікавився й іншими. Паралельно з інтересом до магдебурзького права у вченого все більше з'являлась зацікавленість питанням правового становища старшини і дворянства. Цікавився М. Василенко і проблемою адміністрації в Гетьманщині. Як зазначив сам вчений, цей період історії України викликав у нього інтерес, оскільки мав найбільше суто українських ознак і через це потребував детального дослідження [10, арк. 14]. Саме історії Гетьманщини присвячено переважну більшість його праць.

У передвоєнні роки та в період Першої світової війни М. Василенко стає активним діячем різних київських наукових об'єднань. 3 листопада 1909 р. вчений відновив свою участь у засіданнях «Исторического общества Нестора-летописца» (далі - ИОНЛ), членом якого М. Василенко був обраний ще у 1890 р. Впродовж 1909-1912 рр. він прочитав тут кілька великих доповідей: «Д. Ростовський і його літературна діяльність», «Пам’яті М. Костомарова», «Життя і творчість київського митрополита Є. Болховитінова», «Нові матеріали з історії звільнення селян в Чернігівській губернії» та ін. [18, арк. 305]. Усі ці доповіді, крім першої, були надруковані в «Чтениях исторического общества Нестора-летописца».

3 кінця 1909 р. М. Василенко став активним учасником УНТ у м. Києві. Хоча товариство було засновано ще наприкінці 1906 р. і Микола Прокопович був одним із перших його членів-фундаторів, проте активної участі у його діяльності він не брав, оскільки в той час над ним тяжіли два судові вироки. У 1910 р. М. Василенка обрали головою історичної секції УНТ. У відсутність М. Грушевського (голови товариства) Микола Прокопович заміняв його [18, арк. 310].

31911 р. М. Василенко став одним з трьох редакторів (разом із М. Грушевським і В. Перетцом) «Записок Українського наукового товариства у Києві». Він також виступав від імені товариства перед місцевою адміністрацією. Про це свідчить М. Грушевський у листі до вченого: «Якщо на засіданні будуть сторонні особи, не члени, тоді потрібно взяти дозвіл в губернатора. Потрібно буде завтра поїхати до поліцмейстера, а, можливо, і до губернатора. Крім вас - нікому» [14, с. 5].

20 листопада 1912 р. за поданням М.Грушевського М. Василенка обрали дійсним членом НТШ [9, арк. 1]. Він входив до складу його історико-філософічної секції та Археографічної комісії. На сторінках ЗНТШ було опубліковано кілька праць вченого [7, с. 10]. Тут же відбулася його полеміка 3 М. Слабченком з приводу ідеї останнього про те, що після 1654 р. Україна набула статусу «васальної держави», була «представницькою демократичною республікою з окремими безпосередньо-демократичними інститутами» [1]. М. Василенко закидав молодому колезі «скороспілість» його висновків, хоча й відзначив його безсумнівні наукові здібності.

Ще одним науковим товариством, у діяльності якого активно брав участь М. Василенко, було Товариство любителів соціальних знань. Це товариство було засновано восени 1910 р. професором М. Довнар-Запольським і групою його найближчих учнів. Згодом до них приєднались такі відомі вчені, як Є. Ківлицький, А. Дахнович, Н. Максимов, В. Іконніков, Л. Добровольський. Товариство складалося з трьох секцій: історичної - під керівництвом Є. Ківлицького, географічної - П. Тутковського і юридичної - М. Василенка. На засіданнях читались доповіді з наукових питань, реферувались нові книги, готувалась інформація з оглядом нових досліджень, обговорювалися питання 3 методики викладання [18, арк. 319-320].

М. Василенко брав активну участь у організації діяльності товариства. Особливо багато клопотів було з приводу організації 50-річного ювілею т.зв. «Великої реформи» 1961 р. 3 приводу цього Микола Прокопович прочитав низку доповідей. Він готував також лекцію про кріпацьке право в Україні, 3 якою мав виступити 19 лютого 1911 р. на спільному засіданні ИОНЛ і Товариства любителів соціальних знань. Проте виступити йому на об'єднаному засіданні не довелося [18, арк. 322-325].

У 1910 р. в середовищі київської професури зародилася ідея заснування в Києві археологічного інституту за зразком Петербурзького. Одним із ініціаторів нового інституту був В. Данилевич, який читав в університеті і Вищих жіночих курсах археологію. До ініціативної групи входив і М. Василенко [18, арк. 333-334].

13 жовтня 1910 р. газета «Киевские вести» повідомляла, що затверджено статут приватного Археологічного інституту в Києві, який спочатку було складено у невеликому гуртку, до якого згодом 
приєдналися М. Василенко, В. Кордт, В. Антонович, В. Завітнєвич та ін. [4, с. 70]. 13 грудня 1911 р. Микола Прокопович став членом Чернігівської вченої архівної комісії [8, арк. 1].

У найскладніші часи свого життя М. Василенко продовжував наукову роботу. Праці періоду 1911 - 1912 рр. показово свідчать про його професійний ріст. Дослідник брав участь у написанні таких фундаментальних досліджень, як «Всемирная история» під редакцією професора І. Пфлуга-Гартунга (Санкт-Петербург., 1911), «Великая реформа. 1861 - 1911» (Київ, 1911), «Отечественная война 1812» (Київ, 1912). Наукові статті М.Василенка 3'являються в ЗНТШ та органі УНТ - журналі «Україна».

3 середини 1911 р. вчений став знову писати статті для нового видання словника Брокгауза та Ефрона. Для словника М. Василенко написав статтю про М. Грушевського. Майже половину іiї обсягу займає популярний виклад української історіографічної концепції з суттєвими цитатами з роботи М. Грушевського «Звичайна схема руської історії й справа раціонального укладу історії східнього слов'янства» та 3 передмови до його «Очерков истории украинского народа» [2, с. 155-157]. Участь у новому виданні Брокгауза та Ефрона не стала для Миколи Прокоповича такою серйозною справою, якою була при першому виданні словника, адже в його біографії значились два ув'язнення з приводу антивладних публікацій в «Киевских откликах», де М. Василенко був редактором. У результаті частина його статей була вилучена, а частина була замінена статтями нових авторів.

3 січня 1912 р. М. Василенко став постійно працювати для словника братів Гранат. Вченого було запрошено до участі в цьому виданні завдяки М. Грушевському. Останньому було запропоновано написати низку статей для словника. Із запропонованих одним зі співредакторів, О. Дживілеговим, десяти статей на літеру «Г» М. Грушевський написав лише дві - про М. Глинського та I. Гонту. Зі свого боку Михайло Сергійович запропонував редакторові доручити написання решту статей М. Василенкові. Пропозицію було прийнято, Микола Прокопович написав статтю «Гайдамаччина», що разом з іншими була спершу запропонована М. Грушевському [6, с. 349].

Підтримуємо думку І. Гирича, що саме М. Грушевський засадничо посприяв Миколі Прокоповичу у зміцненні української компоненти його національної свідомості. М. Грушевський неодноразово дорікав М. Василенку у бракові в нього українського патріотизму, на що Василенко відповідав: «Я - українець, але я ніколи не замикався в колі тільки українських інтересів. Мені за це дорікають, дивляться на мене скоса, інколи навіть підозріло. Але що ж поробиш, коли мій світогляд склався так, що я вважаю можливим вирішення українського питання тільки на грунті федеративного устрою Росії, і українське питання не можу виділити від інших національних питань польського, єврейського, латиського і ін.» [5, с. 138].

Упродовж 1910 - 1914 рр. у ЗУНТ та НТШ з'явилися перші україномовні статті М. Василенка. Серед них було п’ять значних публікацій, написаних на замовлення М. Грушевського. Найбільш очевидно перехід М. Василенка на позиції національної концепції української історії помітний у найвідомішій із його наукових студій - «Очерках по истории Западной Руси и Украины» (Київ, 1916). Вона охоплювала історичний період від Люблінської унії 1569 р. до Переяславської ради 1654 р. і побачила світ наприкінці 1915 р. (хоча датована 1916 роком). У передмові до книги М. Василенко висвітлює своє бачення основних моментів українського історичного процесу. Помітно, що він схиляється до схеми М. Грушевського, - вважає вихідним пунктом для історії українського народу Київську Русь i що історія українського народу до 1654 р. була цілком відособленою від історії Московської держави [3, с. 2-4]. Одразу ж після виходу книга завоювала увагу як науковців так і широкого кола читачів і стала найбільш популярною і відомою серед усіх робіт вченого. М. Грушевський в листі до М. Василенка так писав про неї: «Оце так сюрприз, дорогий Микола Прокопович, я і не підозрював, що це буде ціла окрема книга, перша така велика ваша книга. Всі дуже раді і щиро вас вітаю» [11, арк. 18].

Таким чином, наукова діяльність в дореволюційні роки мала важливе значення в контексті формування світогляду М. Василенка. В передвоєнні роки та в період Першої світової війни вчений активізував свої наукові студії. За цей час він публікує низку наукових праць. У них відобразилася прихильність вченого до ідеї української історичної самобутності, яскраво обгрунтованої у творчості М. Грушевського. Вчений був активним учасником різних наукових об'єднань, серед яких ИОНЛ, НТШ, УНТ. Співпраця з видатними постатями українського руху, історичні погляди вченого, втілені в наукових працях цього часу, а також спрямування наукових інституцій, чільним діячем яких він був, дозволяють стверджувати про наявність у національній самосвідомості та політичному світогляді М. Василенка «дореволюційного» періоду виразної та істотної «української» компоненти. 


\section{Список використаних джерел та літератури:}

1. Василенко М. Ще до історії устрою Гетьманщини XVII - XVIII ст. з приводу заміток М. Є. Слабченка. 3НTW. 1913. T.116. C.79-86.

2. Василенко Н. Грушевский Михаил Сергеевич. Новый энциклопедический словарь. Ф. Брокгауз и И. Эфрон. Санкт-Петербург, 1913. Т.15. С.155-157.

3. Василенко Н. Очерки по истории Западной Руси и Украины. Київ, 1916. 589 с.

4. Вороненко В., Кістерська Л., Матвєєва Л., Усенко І. Микола Прокопович Василенко. Київ, 1991. 272 с.

5. Гирич I. Архів М. Грушевського як джерело для вивчення діяльності визначних постатей українського руху (М. Грушевський, С. Єфремов, В. Липинський, М. Василенко): дис... канд. іст. наук. Київ, 1995. 185 с.

6. Гирич I. М. Грушевський і М. Василенко (До історії творчих взаємин). Український археографічний щорічник. Нова серія. В.3/4. Украӥнський археографічний збірник. Т.6/7. Київ, 1999. С.344-355.

7. Гришко В. Пам'яті учителя (В 25-річчя з дня смерти академіка М. П. Василенка). Батьківщина. 1960. Ч.35-36 (1019-1020). C.5-12.

8. ІР НБУВ (Інститут рукопису Національної бібліотеки України імені В. І. Вернадского). Ф.40. Оп.1. Спр.1042. 1 арк.

9. ІР НБУВ. Ф.40. Оп.1. Спр.1135. 1 арк.

10. ІР НБУВ. Ф.40. Оп.1. Спр.1254. 20 арк.

11. ІР НБУВ. Ф.40. Оп.1. Спр.1346-27. 32 арк.

12. ІР НБУВ. Ф.40. Оп.1. Спр.1346-31. 35 арк.

13. Матвєєва Л. Національна Академія наук України: етапи розвитку та доля вчених (історико-джерелознавче дослідження): дис... д-ра. іст. наук. Київ, 1996. 364 с.

14. Петрів М. Конституція 1710 р.: Орлик і Василенко. Київ, 1997. 36 с.

15. Полонська-Василенко Н. Микола Прокопович Василенко

16. ЦДАВО України (Центральний державний архів вищих органів влади та управління України, м. Київ). Ф.3806. Оп.2. Спр.4. 15 арк.

17. ЦДАМЛМ України (Центральний державний архів-музей літератури і мистецтва України, м. Київ). Ф.542. Оп.1. Спр.44. 258 арк.

18. ЦДАМЛМ України. Ф.542. Оп.1. Спр.45. 360 арк. 